\title{
Assessing Anas' Methodology of Undercover Investigative Journalism in the Light of the Doctrine of Free Will
}

\author{
Isaac Boaheng 1
}

${ }^{1}$ Bible Society of Ghana.

\begin{abstract}
Corruption is a major problem in the world but more so in Africa. Different efforts have been put in place to curb this social problem but corruption still persists. In Ghana, investigative journalist Anas Aremeyaw Anas has joined the fight against corruption and has made various revelations that have helped the government and the general populace in one way or the other. Anas' methodology has however attracted various comments from the general public concerning how ethical this approach could be. This article aims at assessing the investigative journalism methodology used by Ghanaian undercover investigative journalist Anas Aremeyaw Anas in the light of the doctrine of free will to determine if this methodology is a breach of free will or not. Analyzing data extracted from articles, books, and others, the paper concludes that the choice of Anas' victims to involve themselves in corrupt practices is done out of their own free will and hence they are fully responsible for their decisions.
\end{abstract}

Keywords: Undercover journalism, Entrapment, Free will, Corruption, Exposé

\author{
Correspondence \\ Isaac Boaheng \\ Email: revisaacboaheng@gmail. \\ com \\ Publication History \\ Received 15th September 2020, \\ Accepted 29th September 2020, \\ Published online 27th October \\ 2020.
}

\section{INTRODUCTION}

One of the major problems in modern societies is corruption. Corruption creates an unjust society that no longer guarantees equal rights and opportunities for its citizens. Individuals, religious, governmental and non-governmental organizations have used different approaches to fight corruption. In Ghana, the context of this study, the present government of Ghana, in an attempt to deal with corruption, has established the office of The Special Prosecutor to deal promptly with people who embezzle public funds. Religious bodies have not only preached against corruption but have put some practical measures in place to reduce it. Yet, many citizens still suffer directly or indirectly from corruption.

The Tiger Eye PI, led by Anas Aremeyaw Anas, is one private organization that, in recent times, has been very active in the fight against corruption through undercover journalism. The results of Anas' investigations have led to the prosecution and jailing of some corrupt individuals to serve as a deterrent to others. While Anas continues to receive applause from many people who see nothing wrong with his practice, others have raised serious issues about the legitimacy of his methodology, which they describe as "entrapment." The investigative journalist hides his true identity in conducting investigations into human rights issues and corruption in Ghana and many parts of the world including Nigeria and Tanzania. He has won many awards, including Best Journalist Awards (Ghana), Heroes acting to end Modern-Day Slavery Award (US) in 2008, and Africa Achievers' Award (Kenya) in 2013. In 2015, he was recognized by Foreign Policy as one of the most influential personalities in the world. His major works so far include the exposé on the use of maggot or weevil-infested flour by a foreign company to manufacture biscuits, an exposé on the poor conditions in Ghana's premier psychiatric hospital, the exposé on the rot at the Osu Children's Home, the exposé at the Elubo border of the Western Region in the matter of the massive smuggling of cocoa to the Ivory Coast, the exposé on the bribery and corruption cases at the Tema Port, the exposé on endemic and systemic corruption by judges, magistrates, and other judicial functionaries, and the exposé on corrupt practices involving the President of the Ghana Football Association. He also has a documentary on the sale of COVID-19 supplies at some hospitals in Ghana and the production of fake drugs. 


\section{Anas' Investigative Methodology}

Anas' methodology involves finding a way to confirm a prima facie case. The approach, though differs from case to case, basically involves the use of human agents and electronic gadgets, like cameras and tape recorders to gather information. As stated earlier, the investigation process is triggered by the suspicion of acts of corruption in an organization. The Tiger eye company may be contracted to undertake the investigation or the company (the Tiger eye) may take the initiative itself. A member of the Tiger eye has to be implanted in the organization to be investigated. Then after that, a preliminary survey is made to confirm or deny the presumptions made. After the survey, the company informs the organization of their readiness to go into full operation. From this time, efforts are made to get members of the investigative team employed in some capacities (eg. sweepers, labourers, secretaries and others). These people then try to fix some cameras at vantage points and later help the other members of the investigative team to get on board to carry on their investigation. There are situations in which a member of the investigative team put a bait (in a form of a bribe or any appropriate item) before the person under investigation who may then falls prey to it.

This kind of methodology of undercover investigative journalism has come under criticism for some time now. However, the documentary, titled "Number 12", which has so far implicated the former President of the Ghana Football Association (GFA), Mr. Kwasi Nyantakyi has revived public interest in the debate surrounding the methodology. Mr.Kennedy Agyapong, MP for Assin Central, considers Anas' methodology as illegitimate and has called for an injunction on Anas' attempt to premier his latest work focusing on football and politics. Hon. Alexander AfenyoMarkin, MP for Effutu constituency, has asked for legal scrutiny of Anas' methodology. He goes further to describe Anas' methodology as unfair, a complete setup and an "invasion of privacy by the journalist." In his view, it is unfair to lead someone "on into something and turn around and pronounce the person 'guilty."' Mohammed Amin Lamptey believes that a proper means of fighting corruption should not cause others to stumble. ${ }^{3} \mathrm{He}$ describes Anas' methodology as one that causes people to sin. This means that the sin committed is not done out of the victim's own free will. He describes a proper investigative methodology as one which comprises "meticulous documentation, first-hand interviews and observations leading to an unimpeachable evidence." He argues further that Anas' "entrapment" is morally and ethically wrong. Commenting on the expose on Football in Ghana, Lamptey states, "If an undercover investigator pretends to be a sponsor of football matches and uses this to keep surveillance on known corrupt match officials, then he has done nothing wrong in reporting what he has seen and heard. But when he uses his position to invite and encourage others to commit a crime rather than just observe, this is entrapment which is crude and immoral, methinks." ${ }^{4} \mathrm{He}$ sees everything wrong with a methodology that seeks to "entice and entrap potential criminals into becoming real ones for the express reason of naming and shaming." He further contends that "if Anas were to dangle any price before the-socalled righteous in our society ... they will sin that very instant." That is why we pray that we should not be led into temptation (The Lord's Prayer). The one who attempts or helps someone to initiate any criminal or immoral behavior is as evil as the one who falls prey to the initiator's bid.

On the other side are those who see nothing wrong with the work of the ace journalist and applaud his efforts. His Excellency Barak Obama, former US president acknowledged Anas' effort in fighting corruption during his visit to Ghana. ${ }^{5}$ Hon. Inusah Fuseini, MP for Tamale Central is also in support of Anas' practice. ${ }^{6}$ His defense is that Anas' investigation is always based on "a prima facie case of some wrongdoing." 7 The nature of the situations Anas' investigates, according to the legislator, demands Anas' methodology shine light on the actors and to expose them. Abdul Malik Kweku Baako, Anas' mentor, argues that Anas' practice is healthy and must not be condemned. ${ }^{8}$ While Baako finds no problem with the debate surrounding the methodology, he cautions those "who seek to criminalise and bastardise the methods as well as the person engaged in that exercise" to desist from such acts. ${ }^{9}$ For him, a legal test of Anas' methodology would mean going to a higher court because "some of the lower courts are currently using his [Anas] evidence as admissible and people are in prison." ${ }^{10}$

The two sides of the debate raise questions such as Is Anas' methodology a breach of free will? Or are the victims responsible for their actions? From both philosophical and theological viewpoints, this current study thus attempts to

\footnotetext{
Ghana Guardian, "It's time to subject Anas' methodology to legal test" accessed August 29, 2020.

https://www.ghanaweb.com/GhanaHomePage/NewsArchive/It-s-time-to-subject-Anas-methodology-to-legal-test-Afenyo-Markin-657251

Mohammed Amin Lamptey, "Anas's mode of investigative journalism unethical, unislamic" accessed June 4, 2018.

https://www.ghanaweb.com/GhanaHomePage/features/Anas-s-mode-of-investigative-journalism-unethical-unislamic-657221

Lamptey, "Anas's mode of investigative journalism unethical, unislamic"

Lamptey, "Anas's mode of investigative journalism unethical, unislamic"

Global Integrity, "Obama in Ghana: Strong Words on Governance, and a Shout Out to Our Reporter" (2009), accessed June 4, 2018 https://www.globalintegrity.org/2009/07/13/post-439/

Ghanaweb, "It's time to subject Anas' methodology to legal test".

Ghanaweb, "It's time to subject Anas' methodology to legal test".

Ghanaweb, "It's time to subject Anas' methodology to legal test".

Ghanaweb, "It's time to subject Anas' methodology to legal test".

Ghanaweb, "It's time to subject Anas' methodology to legal test".
} 
find answers to these questions by examining the said methodology in the light of the doctrine of human free will. The main contention of the study is that, though to some extent Anas' methodology could be described as "entrapment", the choice of his victims to involve themselves in corrupt practices is done out of their own free will and hence they are fully responsible for their decisions.

\section{Free Will and Human Choices}

Free will may be defined as "the mind choosing" or choosing only what the mind approves and rejecting only what the mind disapproves. ${ }^{11}$ "Our inclinations and motives, as well as our actual choices, are shaped by the mind and therefore if the mind is not involved in our choices then we make choices for and with no reason." ${ }^{2}$ Free will also mean "the ability to choose what we want"13 or the power to choose according to one's desires. A free choice is motivated by one's desire or reason. Therefore, human free will is the unique ability to reflect on and evaluate one's desires and to choose one course of action over another. People therefore make choices according to their strongest inclination and this makes their choices free and self-determined.

There are three major philosophical/theological positions regarding human choices, namely, determinism, self-determinism and indeterminism. Determinism, according to Joel Feinberg, refers to "the theory that all events, including human actions and choices, are, without exception, totally determined"14 by external factors. This position is divided into two. The naturalistic view of determinism holds that human behavior can be fully explained in terms of natural causes. In this case, human beings are considered as part of the machinery of the universe. Thomas Hobbes and B.F. Skinner are examples of advocates of this view. The second view of determinism, called Theistic determinism traces human actions to God's controlling power. Martin Luther and Jonathan Edwards are examples of advocates of this view. ${ }^{15}$

Self-determinism holds that a person's acts are caused by him/herself. Self-determinism accepts the fact that environmental and hereditary factors may influence one's behavior but denies that such factors are the determining causes of one's behavior. Thomas Aquinas and C. S. Lewis are prominent advocates of this view. ${ }^{16}$

Indeterminism, as the name implies, is the logical contradiction of determinism. ${ }^{17}$ According to Joel Feinberg, determinism means for every event, including human interactions and choices, there exist conditions that could cause no other event. ${ }^{18}$ More specifically, it can be defined as the theory that human behavior is uncaused. In other words, there are no antecedent causes of a person's actions such that any human act could have been otherwise. Indeterminists usually appeal to Heisenberg's principle of uncertainty for support to their claim. This principle states that it is impossible to predict where a subatomic particle is and how fast it is moving at a particular moment. Based on this theory, it is argued that if the behavior of the subatomic particle is unpredictable, then there is no way we can predict that of a human being. ${ }^{19}$

\section{Adam's Sin: Who is Responsible?}

The origin of sin in the history of humankind could be traced back to the early chapters of the book of Genesis. God after creating human beings placed them in the Garden of Eden (Gen. 2). In the Garden environment, God made provision for all the person's physical, social, and spiritual needs. In the center of Eden God placed two trees, the tree of life and the tree of the knowledge of good and evil (Gen. 2:9). God asked them to eat from all the trees except the tree of the knowledge of good and evil. In so doing, God gave them the responsibility to make the right choice and to reject the wrong option. Adam and Eve were therefore placed in a condition of innocence such that their will and affections were capable of inclining either to good or evil. Humans could move to a state of confirmed righteousness only by a process of testing and moral decision making. In the divine plan, Adam and Eve must determine whether they would live righteously under God's liberating authority or whether they would pursue living independently of their Creator.

Humankind by nature is a self-conscious, self-determining being, a moral agent with the capacity for performing moral action. Moral action in turn demands a law by which character is determined - a law which may be either obeyed or disobeyed by the subject. Such a law is necessary because it provides the moral quality to which either praise or blame could be attached. ${ }^{20}$ Without such a moral quality, the character of the moral agent would be destroyed. Willey therefore notes that if God was to be glorified by humankind's free service, it was necessary for the human being to be on

\footnotetext{
1 Robert.C. Sproul, Chosen by God, (Illinois: Tyndale Publishers, Inc., 1986), 53.

12 See Sproul, Chosen by God, 53.

3 Sproul, Chosen by God, 55.

4 Joel Feinberg, Reason and Responsibility (Belmont, CA: Wadsworth Publishing Company, 1989), 342.

5 Feinberg, Reason and Responsibility, 343.

6 Feinberg, Reason and Responsibility, 343.

17 Feinberg, Reason \& Responsibility, 343.

8 Feinberg, Reason \& Responsibility, 342.

19 Feinberg, Reason and Responsibility, 343.

H. Orton Willey, Introduction to Christian Theology (Missouri: Beacon Hill Press, 1946), 162-163.
} 
probation in the Garden and subjected to temptation so that the power to choose could be utilized. ${ }^{21}$

The Bible teaches that sin began with the transgression of Adam in the Garden of Eden (Gen. 3). The historicity of this event is essential if an analogy is to be seen in Romans 5:12-21. Christ confirms Genesis 3 as a historical event (Matt. 19:3-5). It was a perfectly voluntary act on the part of the human being. The tempter came from the spirit world with the suggestion that the human being, by placing him/herself in opposition to God, might become like God. Adam yielded to the temptation and sinned by eating of the forbidden fruit (Gen. 3: 1ff).

Adam and Eve's disobedience raises significant questions about human free will. Were the original humans free? If so, of what did their freedom consist? Are people free in the same sense? It has been earlier discussed that three possibilities exist for every human choice namely: Adam's action was caused by another (which is determinism), Adam's action was uncaused (which is indeterminism), or Adam's action was caused by himself (which is self-determinism). Determinism does not apply because, as it is seen, God did not cause Adam to sin and also God can neither sin nor tempt anyone else to do so (James 1:13). God cannot be regarded as the author. God's eternal decree certainly rendered the entrance of sin into the world certain, but this cannot be interpreted to make God the cause of sin in the sense of being its responsible author. This idea is excluded by Scripture: "Far be it from God that He should do wickedness and from the Almighty, that He should commit iniquity" (Job 34:10). "He is the holy God" (Isa. 6:3) and "there is no unrighteousness in His" (Deut. 32:4; Ps. 92:16). Neither did Satan cause Adam to sin, for the tempter did only what his name implies, neither forcing him to do it nor doing it for him. Concerning indeterminism, there was no evil (or lack of wholeness) in Adam's nature that gave rise to his sin, for he had none-God created him perfect (Gen. 1:30). Besides, there are no uncaused actions for this would violate the principle of causality. No event is without a cause, and there was nothing in heaven or on earth, outside of Adam, that caused his sin; he must have caused it himself; Adam's choice was self-determined. This is the heart of human freedom; namely, "the ability to be the efficient cause of one's own moral actions."22 Acts of which one is not an efficient cause, but rather which are forced, are not free moral acts.

Adam's sin arose out of his free choice even though the Devil tempted him. God created humankind and gave them the right to choose between right and wrong. On their own volition, he chose wrong. He was free to do as he pleased and he abused that freedom. The first human beings were free to sin or not to sin. Adam abused the freedom of choice and thus sinned. God did not author it, nor did He create it - God only allowed it. This is not God's fault, nor His responsibility. Therefore, "The original sin was a declaration of moral independence from God." ${ }^{23}$ Sin comes as a result of the misuse of free will. Thus, Geisler has said "...the power of moral free choice entails the ability either to choose the good God designed for us or to reject it. ... If God made free creatures, and if it is good to be free, then the origin of evil is in the misuse of freedom." ${ }^{24}$

Every person, like Adam, is responsible for his/her actions, for at least two reasons: First, God's decree concerning sin is not causative but permissive, directive, preventive and determinative. God's decree permitted the entrance of sin into the world for reasons that are fully known only to Him. Thus, if it must, then it would only come through the wrong exercise of human free will in a free choice. God does not compel people to sin; he only allows people to exercise their wills freely. Humankind, and not God, is the efficient cause of sin; and for that reason, he/she is responsible. For example, in the case of Pharaoh, whose heart God said He had hardened to demonstrate His glory, it was Pharaoh himself who was the efficient cause of his sins, not God. God could therefore not be accused of sinning because Pharaoh sinned willingly. Second, the law of God and not His decree fixes a person's duty and responsibility. As God's revealed will, the law of God is people's guide and standard. Humankind has nothing to do with this except to know and acknowledge the facts concerning it. The motivation for sin makes people responsible for their sins.

\section{Free Will as Basis for Praise or Blame}

Human free will forms the basis for praise and blame. Free will guarantees individual responsibility or makes one culpable for his or her life choices; otherwise, there could be no basis for praise or reward for one's action. Human free will serves as the basis for deserving praise for a good choice or deserving blame for a bad choice. Had it not been the freedom Adam and Eve had to make their own choices, they could not have received condemnation for their actions.

The concept of free will is closely linked to the concepts of responsibility, praise, guilt, sin, and other judgment which apply only to actions that are freely chosen. It is also connected with the concepts of advice, persuasion, deliberation, and prohibition. First of all, it must be noted that human behavior is regulated by many factors, including moral standards, the sense of shame, conscience, duty, and so on. The basic manifestations of the ethical life are the sense of social and personal responsibility and the awareness of guilt that this implies. In this regard, responsibility is not only a moral category but also a psychological, legal and socio-political one.

\footnotetext{
21 Willey, Introduction to Christian Theology, 162-163.

22 Norman L. Geisler, Systematic Theology Vol. 3 (Minneapolis: Bethany House, 2011), 1041.

23 Lynn Gardner, Where Is God When We Suffer?: What the Bible Says about Suffering (Missouri: College Press Publishing Company, 2007$)$, 48.

24 Norman Geisler, Chosen but Free (Minneapolis: Bethany House Publishers, 1999), 22.
} 
Traditionally, only freely willed actions are seen as deserving credit or blame. There are numerous different concerns about threats to the possibility of free will, varying by how exactly it is conceived, which is a matter of some debate. Without free will, humankind will be innocent of everything he/she does. Kantian approach to the issue sees responsibility for actions as relying on forms of self-control that point back to the idea of free will. Kant contends that "praise and blame are justified because a person freely chooses his/her actions." 25 This means that praise and blame respond to the person as the chooser of his/her deed; they recognize his/her dignity as a rational agent. Thus, free will manifests itself precisely in purposeful activity. To sum up, freedom is the ability, based on knowledge of necessity, and to choose and to act in accordance with this necessity. It consists not only in a knowledge of natural and social laws but also in the practical realization of this knowledge.

\section{Anas' Methodology is not a Breach of Free Will}

A sinful person's capacity of self-determination is fully free when he/she has both;

(1) an uncoerced ability to choose among available alternatives (apart from spiritual things) and (2) an ability to do what he/she desires.

The people who fall prey to Anas' strategy act freely because they choose and act according to their natures. Their sinful choices, desires and acts are not coerced from outside themselves. Freely and habitually they determine their choice/ behaviors according to their natures. When choosing and acting according to their sinful natures (doing what comes naturally) these people still have a free choice among the alternatives available to persons unable to receive spiritual things and self-determination within the limits of a world curved in upon themselves. The one who takes a bribe from Anas could decide not to take it. The one who smuggles cocoa with Anas could decide not to do so. However, the choices available to them are limited by their sinful inclinations. Humans are not the pawns or mere victims of alcohol or other kinds of substances in their environments. Therefore, the people found to be corrupt based on Anas' investigation are fully responsible for their choice. In general, personal agents are responsible for their responses to the influences of their peers, subcultures and cultures. "No matter how powerful the external forces," Bernard Ramm argues, "there is a strip of responsibility in every such psyche that cannot be negotiated away."26

\section{CONCLUSION}

The study sought to answer the questions: Is Anas' methodology a breach of free will? Or are the victims responsible for their actions? Anas' methodology does not coerce anyone into choosing to do wrong. His method is a way of giving humanity the opportunity of exercise their free will. One cannot exercise free will without having various alternatives. It is a fact that some of his victims might not go and chase bribe on their own. Yet, the fact that they accept it from the investigative team points to their corrupt nature. There are instances whereby people have been "entrapped" by Anas and they refused to fall prey because they decided to hold on to their integrity.

As the temptations of Adam, there are instances in which temptations will come one's way. Those who are truly committed to Christ will not yield to the temptation. If someone yields to temptation, he/she cannot go to God and say "I am not guilty because I was tempted." This is seen clearly in Genesis 3 where God pronounces judgement on Adam and Eve after they disobeyed Him through the temptations by Satan. Christ is the example in all cases. He was tempted thrice by the Devil but overcame all the temptations because he was determined to remain holy. To conclude, the choice of Anas' victims to involve themselves in corrupt practices is done out of their own free will and hence they are fully responsible for their decisions.

\section{ABOUT AUTHOR}

Isaac Boaheng is an Ordained Minister of the Methodist Church Ghana serving the Nkwabeng Circuit of the Sunyani diocese. He also serves as a Translator for the Bible Society of Ghana. Isaac holds a Master of Divinity degree from the Trinity Theological Seminary, Accra, Ghana and has research interest in Public Theology, Biblical Studies, and African Christianity

\footnotetext{
25 Immanuel Kant, Groundwork to the metaphysics of morals (Cambridge: Cambridge University Press, 1998 ), 67.

26 James Daane, The Freedom of God (Grand Rapids: Eerdmans, 1973), 60.
} 


\section{BIBLIOGRAPHY}

Daane, James. The Freedom of God. Grand Rapids: Eerdmans, 1973.

Gardner, Lynn. Where Is God When We Suffer?: What the Bible Says about Suffering. Missouri: College Press Publishing Company, 2007.

Geisler, Norman L. Chosen but Free. Minneapolis: Bethany House Publishers, 1999. . Systematic Theology Vol. 3. Minneapolis: Bethany House, 2011.

Ghana Guardian, "It's time to subject Anas' methodology to legal test". Accessed August 29, 2020 https://www.ghanaweb.com/GhanaHomePage/NewsArchive/It-s-time-to-subject-Anasmethodology-to-legal-test-Afenyo-Markin-657251

Global Integrity, “Obama in Ghana: Strong Words on Governance, and a Shout Out to Our Reporter" (2009). Accessed June 4, 2018. https://www.globalintegrity.org/2009/07/13/post-439/

Feinberg, Joel. Reason and Responsibility. Belmont, CA: Wadsworth Publishing Company, 1989.

Kant, Immanuel. Groundwork to the metaphysics of morals. Cambridge: Cambridge University Press, 1998.

Lamptey, Mohammed Amin. "Anas's mode of investigative journalism unethical, unislamic". Accessed on June 4, 2018 https://www.ghanaweb.com/GhanaHomePage/NewsArchive/Anas-s-mode-of-investigative-journalismunethical-unislamic-657221

Sproul, R.C. Chosen by God, Illinois: Tyndale Publishers, Inc., 1986, 53.

Willey, H. Orton. Introduction to Christian Theology. Missouri: Beacon Hill Press, 1946. 